\title{
The Liberation Movements In Mindanao: Islām As A Thrusting Force
}

\author{
Marjanie Salic Macasalong \\ International Institute of Islamic Thought and Civilization-IIUM
}

\begin{abstract}
The Contemporary Liberation Movements In Mindanao Have Sprung Up Since The Independence Of The Philippines In 1945. These Liberation Movements Were Formed As A Direct Consequence To The Brutal Policies, Such As The Jabidah Massacre And The ILAGA-Related Massacres, Perpetuated By The Military Forces And Government-Backed Vigilante Groups. The Research Has Been Undertaken With The Objective Of Exploring Various Factors That Sustain The Long Struggle Of The Bangsamoro People For Self-Determination. Through Numerous Sources And Surveys, It Was Found That Islam Has Been The Thrusting Force Behind The Liberation Movements In Mindanao. The Bangsamoro People In General Support Any Movement That Epitomizes Islam In Its Cause. The Researcher Employs Qualitative And Quantitative Approaches In The Study. Historical-Analytical Method Is Also Used For The Brief And Concise Background Of The Study. Data For This Research Are Collected Both From Primary And Secondary Sources Such As Books, Articles, Journals, Newspapers, Government Reports, Non-Governmental Organization's Reports, Policy Statements, Press Releases, Signed-Agreements, And Feedback From The Questionnaires Carried Out By The Researcher.

Keywords: ASG, Bangsamoro, BIFF, Liberation, Mindanao, MILF, MIM, and MNLF.
\end{abstract}

\section{Introduction:}

The Republic of the Philippines has freed itself from the United States of America when the latter granted complete independence to the Filipino people on July 4, 1946. This turned a new era for the Filipino people as they began to run their own affairs without interference from their former colonial master. Filipino politicians assumed offices in the government. Regular elections are institutionalized in order for the eligible voters to choose their next leaders from the highest down to the lowest levels.

However, the Muslims in the southern part, which is known as "Moros," remained a problem to the newly-born republic. The Moros protested the inclusion of Mindanao and Sulu to the Philippines for they believed that it was illegal and unethical for the America to include their areas, as they were not effectively conquered by the colonial powers.

The Moros tried to pursue their legitimate rights through peaceful means. Some of the Moro leaders even entered into politics and began to advocate the embodiment of the Muslim rights to the constitution and the laws of the country. This kind of good cooperation, on the other hand, was not well reciprocated by the government. Instead, its policies towards the Muslims in general were considered as part of an assimilation program and an ethnic cleansing. These became the reason and "triggering events" for the Muslims to realize the urgency of having their liberation movements in order to safeguard their lives from what they called neocolonialism.

The Jabidah Massacre that took place on March $17,1968^{2}$ was the first to highlight the bellicose treatment of the government to the Moros. This massacre took the lives of $64^{3}$ young Muslim trainees in the Philippine Army (PA) by their Christian superiors. According to the lone survivor, Jibin Arola, the trainees wanted to back out upon discovering that the real mission of their training was to invade Sabah and not to fight the Communist insurgency, as they were told during their recruitment. ${ }^{4}$ Uproars and demand for justice were heard all over the country, including in the Capital. Muslim students and demonstrators in Manila held a weeklong vigil in front of the Malacañang Palace, the President's office, demanding justice for the victims. In spite of this, the protest went unheeded.

ILAGA-related massacres were another hostile incidents that led to the death of hundreds of Muslims. Ilonggo Land Grabbing Association, or popularly known as ILAGA, was a militant group primarily concerned with taking land from the Muslims through force and killings. It also enjoyed the support of Christian investors,

\footnotetext{
${ }^{1}$ This description is first used by Macapado Muslim in his book "The Moro Struggle in the Philippines: The Nonviolent Autonomy Alternative."

${ }^{2}$ Salah Jubair, Bangsamoro: A Nation under Endless Tyranny, (Kuala Lumpur: IQ Marin SDN BHD, 1999$), 132$.

${ }^{3}$ Ibid.

${ }^{4}$ Marites D. Vitug \& Glenda M. Gloria, Under the Crescent Moon: Rebellion in Mindanao, (Quezon City: Ateneo Center for Social Policy and Public Affairs, 2000), 4.
} 
logging magnates and the military constabulary in the Philippines. ${ }^{5}$ For just two years, the group had perpetrated more than 20 massacres all over Mindanao that led to the death of hundreds of Muslim civilians and destruction of houses and mosques. Not only that, the group also mutilated bodies of victims, such as carving out ears, slashing nipples, plucking out eyes, and marking bodies with a cross. ${ }^{6}$

One of the massacres that carried out by this group was the incident in Manili, North Cotabato. It was on June 19, 1971, when seventy Muslim civilians - including women and children - were mercilessly massacred inside a mosque. The story of Teng Addie Nagli, one of the surviving victims of the massacre, is worthy of quoting to have a clearer depiction of this incident. He recalls that:

The community was called for a meeting inside the mosque at dawn by Philippine Constabulary (PC) Captain Langgan. He said, men, women and children braved the rain and biting cold to be able to attend the meeting. We had no idea that the supposed-to-be peace and order meeting would snuff the lives of many of our relatives and neighbours. When all the people were inside the mosque, the armed men bolted the men's entrance but kicked open the women's entrance. Then the armed men ordered (my) father to go out and surrender his guns and other firearms, (but) we had no firearms so there was nothing to surrender. They brought my father to our house a few meters away from the mosque and then I heard shots. They killed my father at close range. Captain Langgan then told the people inside the mosque to call on their God and pray because they would all be killed. So they lobbed a grenade at the mosque and I felt myself lifted from the ground. Then I saw body parts stick to the ceiling of the mosque. $^{7}$

Nagli further recalls that others who were nearer to the grenade shielded him, hence he survived. As he recalls, "all I can remember (was) the blood was so warm and bodies heaped all over me so the soldiers did not see me still alive." He said that he could not forget the stench of the ankle-deep blood, which flooded the floor of the mosque. Nagli added painfully that "when the armed men were no longer around, (I) saw all the dead lying in a pool of ankle-deep blood. There was a child with a hack wound on the head; an old man with a dagger still stuck to his right waist. This is (when) I cried. I'll never forget what I saw till the day I die. Even up to now when I think about it, my heart tightens. It makes me want to take revenge because the wounds of the incident are still here." $"$

The Manili Massacre is just one of the more than 20 incidents perpetrated by the group from 1970 to 1972 in the Cotabato province alone. Other incidents included Upi on March 22, 1970 and September 10, 1970 that claimed 12 lives; Polomolok on August 10, 1970 with eight casualties; Midsayap on December 16, 1970 with 18 casualties; Bagumbayan on January 1, 1971 with 12 casualties; the two incidents in Buldon on August 5, 1971 and August 9, 1971 with 14 and 60 casualties respectively; and the two incidents in Alamada on December 3, 1970 and January 17, 1971 with 13 and 73 casualties, respectively. In Cotabato province alone, more than 300 Muslim civilians were massacred, and countless houses and properties were burned and looted.

As a result, the Muslim leaders and politicians became united in calling for the independence of Mindanao. Among the most outraged Muslim leaders were Datu Udtog Matalam, the former governor of Cotabato province, who later on founded the Muslim Independence Movement (MIM); former Senator Ahmad Domocao Alonto of Lanao del Sur who organized the Ansar el Islam; Nur Misuari, a student leader and professor from the University of the Philippines, who later on became the chairman of the Moro National Liberation Front (MNLF); Salamat Hashim, a graduate and student leader from Al-Azhar University, who broke away from the MNLF and founded his own Islamic movement - the Moro Islamic Liberation Front (MILF). ${ }^{9}$

Consequently, this formation of liberation movements became the main pretext of the Marcos regime to declare Martial Law in 1972. This was the pinnacle of all oppressions that had resulted to an estimated number of 60,000 to 80,000 civilian casualties, most of whom were Muslims, ${ }^{10}$ the displacement of around 1 million Muslims, and the emigration of about 200,000 to 300,000 Muslim refugees to Sabah that to date, with the exception of a few, have not returned to their villages. ${ }^{11}$ In the eyes of the Muslims, the declaration of Martial Law was aimed primarily to disarm them, to facilitate their conversion to Christianity, and for the dispossession of their properties. ${ }^{12}$

\footnotetext{
${ }^{5}$ Thomas M. McKenna, Muslim Rulers and Rebels: Everybody Politics and Armed Separatism in the Southern Philippines, (Berkeley: University of California Press, 1998), 151-153.

${ }^{6}$ Cesar Adib Majul, The Contemporary Muslim Movement in the Philippines, (Berkeley: Mizan Press, 1985), 50.

${ }^{7}$ Raqs-Special Features, 15 September 2007, <http://raqs-specialfeatures.blogspot.com/2007/09/memories-of-manili-massacre.html> (accessed 6 February 2012).

${ }^{8}$ Ibid.

${ }^{9}$ Macapado Abaton Muslim, The Moro Armed Struggle in the Philippines: The Nonviolent Autonomy Alternative, (Mindanao State University: University Press and Information Office, 1994), 93.

${ }^{10}$ Ibid.

${ }^{11}$ Thomas M. McKenna, 156.

${ }^{12}$ Ministry of Foreign Affairs Manila, "From Secession to Autonomy: Self-Government in Southern Philippines," 21 September1980, 5.
} 
These incidents resulted to various liberation movements in Mindanao.

\section{The Liberation Movements In Mindanao: Islām As A Thrusting Force Mindanao Independence Movement (MIM)}

The Mindanao Independence Movement (MIM) ${ }^{13}$ was formed in 1968 as an immediate response to the gruesome Jabidah Massacre. Barely two months after the massacre, former Cotabato governor Datu Udtog Matalam declared the formation of the MIM with the aim of establishing an Islamic Republic of Mindanao and Sulu. ${ }^{14}$ This was the first official declaration, after the independence of the Philippines, to establish an Islamic Republic in Mindanao and Sulu.

On May 1, 1968, Datu Udtog Matalam issued the manifesto of his movement that enumerates the reasons of choosing to separate Mindanao and Sulu from the Philippine. More importantly, the idea of founding an Islamic State was unequivocally invoked. In its preamble, it is clearly stated that the Moro inhabitants of Mindanao, Sulu and Palawan "...make manifestation to the whole world its desire to secede from the Republic of the Philippines, in order to establish an Islamic State that shall embody their ideals and aspirations..." "15 Additionally, the manifesto stipulates that in order to fulfil this aspiration, Islām - as an ideology and way of life - must have a definite territory for the exercise of its tenets and teachings, and for the observance of its laws. Furthermore, the MIM constitution and by-laws clearly pronounce in Article IV, Section 4, that the "movement shall be guided by the principles and teachings of the Holy Qur'an and the Sunnah of the Holy Prophet (May peace and the blessings of Allāh be on Him)."

The manifesto went further to invoke the principle of the United Nations' Charter and the Declaration of Human Rights that all people forming the minority in a given state possess the right to self-determination. The Islamic World Congress that affirms the inviolable principle of self-determination, particularly on the rights of the Muslims who are in the minority in given non-Muslim states, was also invoked. MIM also stated that the other reason of this secession was the "systematic extermination of the Muslim youth - like the Corregidor Fiasco [Jabidah Massacre] - and the policy of isolation and dispersal of the Muslim communities that have been pursued vigorously by the government to the detriment of the Muslims."

The MIM also recognizes the importance of armed-resistance from external incursion; hence it paid equal importance of forming its own military arm. Subsequently, "Blackshirts" came into existence, which was mainly composed of young vigorous Moros who were given "months of rigid training" in the Middle East and nearby Muslim countries. ${ }^{16}$ After they returned home, Blackshirts became the vanguard of the Moros against the ILAGA.

The manifesto of the movement is a sufficient proof that the main objective was to have an Islamic and independent State. How the Moros reacted to this, however, is entirely a different story. The MIM did not last long and was not able to galvanize the whole of the Moros in Mindanao and Sulu. It basically ended in 1971 when President Marcos had reportedly met Matalam in Manila. One account further reported that Matalam in fact surrendered to the government in December $1972 .{ }^{17}$ Nonetheless, whether Matalam really surrendered or not, is not the focus of this study. The main contribution and legacy of his MIM is the real concern, and it should not be underestimated. For apart from the very fact that it revived the spirit of the Moros to have an Islamic and completely independent state, the professionals and students in Manila, who latter formed the MNLF, and the first batch of trainees to undergo guerrilla training in a nearby state, were all moved by the spirit and tutelage of the MIM. ${ }^{18}$ In fact, as Gowing noted, "the seeds for what blossomed into the Moro National Liberation Front (MNLF) were sown by this group." 19

\section{Moro National Liberation Front (MNLF)}

Nur Misuari founded the MNLF based on Islamic principle that injustices and oppression should be combated. This is contrary to the popular notion that he only founded the organization as a direct response to the Jabidah Massacre. In his most recent authorized biography, Misuari hinted that no other factors apart from the

\footnotetext{
${ }^{13}$ The original name of the movement was Muslim Independence Movement. It was renamed as Mindanao Independence Movement to emphasize the clamor for justice and equality for every ethnic group in Mindanao.

${ }_{14}^{14}$ T. J. S. George, Revolt in Mindanao, (Kuala Lumpur: Oxford University Press, 1980), 133.

15 The manifesto of the Muslim Independence Movement, Mindanao Independence Movement, May 1, 1968, Pagalungan Darul Islam, Cotabato, Philippines.

${ }^{16}$ Robert D. McAmis, "Muslim Filipinos: 1970-1972”, in The Muslim Filipinos: Their History, Society and Contemporary Problems, edited by Peter G. Gowing and Robert D. McAmis (Manila: Solidaridad Publishing House, 1974), 46.

${ }^{17}$ W. K. Che Man, Muslim Separatism: The Moros of Southern Philippines and the Malays of Southern Thailand, (Singapore: Oxford University Press, 1990), 77.

${ }^{18}$ Salah Jubair, 134-135.

${ }^{19}$ Peter Gordon Gowing, Muslim Filipinos: Heritage and Horizon, (Quezon City: New day Publishers, 1979 ), 192.
} 
injustices and oppression perpetrated by the erstwhile colonial powers and the current Manila government that made him think of fighting. ${ }^{20}$

Commonly branded as secular and nationalist, ${ }^{21}$ Misuari had grown up in an environment where Islām and Qur'ān had been dominant. His parents were devout Muslims and were responsible for imparting on him the knowledge on how to be a defender of Islām. His mother taught him how to read the Qur'ān; while his father brought him along to the mosque and made him stay until late at night for Islamic teachings. At a very young age, Misuari was already taught how to perform the basic Islamic rituals, how to live in accordance with Islamic principles, and most of all how to defend the religion and the motherland. Even when he was just a baby, he was being sung with a traditional lullaby every time his mother put him to bed each night: "Sleep my child, so you can grow up, to be a strong warrior." ${ }^{, 22}$ Thus, Misuari grew up with the constant inculcation of the desire to fight injustice and oppression.

Prior to his departure to Manila for his university education, Misuari recalled how his father held his arm and passed the bequeathal Will of their ancestors:

You are leaving. Look at me; I'm already old. I would like to reveal to you what our family has bequeathed to us. Your grandfather, Panglima Sayed, who was martyred, left a Will which said, 'Go and fight. If you cannot prevail, give this Will to seven generations.' I'm not sure you will see me alive again, my son. Because of this Will, I want you to pass along the fight of seven generations for our land and people. ${ }^{23}$

Misuari's ancestors, both paternal and maternal, could all be traced back to the royal Sulu Sultanate who defended the land and religion to their deaths. According to him, his father was the "youngest of six brothers descended from a line of warriors who defended the sovereignty of the Sulu Sultanate from the Spanish", and his grandfather, Panglima Saladdin, was the "bravest of men and toward the end of the Spanish era in the Philippines, he led the destruction of the Spanish garrisons in Tawi Tawi and forced their garrison in Siasi to surrender." As for his mother, she was the "great-granddaughter of famous warriors of the Bangingi clan who fought against Spain at sea". ${ }^{24}$ From both sides, Misuari is a descendant of those who fought against colonialism.

During his time in Manila, Misuari became more adamant to fight the neo-colonial government when he witnessed the economic gaps between Sulu and Manila, and the decline of Sulu and Mindanao from their glorious years before European invasions. For him, it is in the Qur'ân to combat against such oppression and injustice. ${ }^{25}$ Fuelled by religious teachings and the bequeathed Will of his father, Misuari was more steadfast than anybody else. In the MNLF Manifesto, he enumerated all the grievances, oppressions and injustices against the Bangsamoros and asserted those as the reason to have an Independent Bangsa Moro Republik. The manifesto declared that:

The five-million oppressed Bangsa Moro people wish to free themselves from the terror, oppression and tyranny of Filipino colonialism which has caused them untold sufferings and miseries by criminally usurping their land, threatening Islām through wholesale destruction and desecration of their places of worship and their Holy book, and murdering their innocent brothers, sisters and old folks in a genocidal campaign of terrifying magnitude. ${ }^{26}$

The Jabidah Massacre was just a supplemental to Misuari's long conviction to fight against oppression and injustice. This became the most triggering and thrusting incident that forced the Muslim leaders, especially Misuari, to found the MNLF.

In 1969, Nur Misuari and other Muslim youth leaders secretly founded the MNLF. For strategic reason, Nur Misuari decided to continue operating under the Bangsa Moro Liberation Organization (BMLO), an organization which was formed by the Moro aristocrats and politicians to arrange and send young Moros abroad for guerrilla training. This decision was to further strengthen the newly founded organization. It was only in 1973 that MNLF began to surface as a distinct organization.

Subsequently, with the financial assistance and arms shipments from the OIC members, most notably Libya, ${ }^{27}$ Sabah (Malaysia), ${ }^{28}$ Saudi Arabia and Iran, ${ }^{29}$ the MNLF began to emerge as the strongest organization

\footnotetext{
${ }^{20}$ Tom Stern, Nur Misuari: An Authorized Biography, (Manila: Anvil Publishing Inc., 2012), 18-19.

${ }^{21}$ Nur Misuari is widely believed to be secular and a nationalist because of his Western type of education and his emphasis on the idea of Nationalism, rather than Islamic ideology. His primary concern is to liberate the Muslim areas with a democratic type of government.

${ }^{22}$ Tom Stern, 8.

${ }^{23}$ Tom Stern, 11

${ }^{24}$ Tom Stern, 8.

${ }^{25}$ Tom Stern, 18-19.

${ }^{26}$ Official Manifesto of Moro National Liberation Front.

${ }^{27}$ In 1972 Misuari obtained US \$3.5 million from Libya. From 1973-75, Libya is the MNLF's chief diplomatic and political supporter. On top of it, arms and other military equipment were also provided. Qaddafi's motives are officially stated as support for Islam. However, according to one author, it is generally acknowledged that Qaddafi was seeking to enhance his image as a leader of stature of the Islamic
} 
in Mindanao. The organization was even able to provide and supply weapons and other war-related materials to individuals and other Muslim groups who were already at war against the government forces. ${ }^{30}$ During its zenith in 1973 and 1974, MNLF was reported to have at least 15,000 fighters, and possibly twice that number in its reserve. ${ }^{31}$ By 1975, the BMA was able to field some 30,000-armed fighters. ${ }^{32}$ Massive and solid support from the Bangsamoro people all over Mindanao also backed up the organization. During that time, at least 55 per cent of the Muslims supported the MNLF, ${ }^{33}$ either by personally involving themselves in the organization or by contributing in terms of financial and logistical support.

In addition to the support of the OIC that made the MNLF stronger, other domestic factors also contributed to its strength. One significant factor is the ideology of the organization. It follows a nationalistic ideology in which the liberation of Mindanao is the primary concern, and a democratic type of governance would be followed should victory be achieved. In the manifesto (Declaration of Independence) of the MNLF, it was declared that:

The Bangsamoro People and Revolution is a revolution with a social conscience. As such it is committed to the principle of establishing a democratic system of government which shall never allow or tolerate any form of exploitation and oppression of any human being by another or of one nation by another nation. ${ }^{34}$

In pursuit of this ideology, MNLF envisions an egalitarian concept. ${ }^{35}$ It affirms and promotes the principle of equality of all people in the political, economic, social, and civil right aspects regardless of differences in religion, race, ethnic origin, and gender. This ideology and concept galvanized the support of the Bangsamoros, Lumads and even some Christians in Mindanao to work together against the government.

With such a strong backing, MNLF had brought the Bangsamoro plight to the international arena. Nur Misuari had managed to make the Muslim communities aware of the suffering of the Moros and the genocidal campaign by the government. OIC members recognized the MNLF as the sole and legitimate representative of the Bangsamoro people, and subsequently granting Misuari the observer status in the OIC. This gave him special access to the Muslim world.

Moreover, a series of negotiations between the government and the MNLF were initiated. During the initial stage, MNLF demanded complete independence. ${ }^{36}$ However, Misuari had to downgrade this to autonomy since the OIC members seemed unsupportive of any demand for complete independence. In 1974, OIC made a historic resolution urging both parties to settle their problems within the premises of the national integrity of the Philippines. OIC Resolution No. 18 of the Political Committee at the fifth Islamic Conference of Foreign Ministers urged the Philippine Government to find a political and peaceful solution through negotiations with Muslim leaders, particularly with representatives of the MNLF in order to arrive at a just solution to the plight of the Muslims within the "framework of the national sovereignty and territorial integrity of the Philippines." It further noted that the Mindanao conflict is an internal problem of the Philippines.

This particular resolution was very painful to Misuari as he had to abandon his demand for complete independence. As he admitted:

The primary reason why we had to accept that resolution was because we were terrified at the prospect of being isolated from our brothers in the world. I told them (the OIC) that this is a very, very difficult choice you are giving us. It's like putting a bar of hot iron down our throats

and Arab worlds, attempting to replace Nasser, who died in 1970, and to extend his own influence and further the "world revolutionary struggle". See Alexis Heraclides, "The Self-Determination of Minorities in International Politics, (London: Frank Cass and Company, Ltd., 1991), 174.

${ }^{28}$ Tun Mustapha of Sabah supplies aid to the Moros partly out of sympathy for the Muslim cause. See Aruna Gopinath, "International Aspects of the Thai Muslim and Philippine Muslim Issues: A Comparative Study", in Internationalization of Ethnic Conflict, edited by K.M. de Silva and R.J. May, (London: International Centre for Ethnic Studies, 1991), 131. However, it was also reported that Mustapha has harbored animosity against the Philippines since it announced its claim to Sabah in 1962. See Astri Suhrke and Lela Garner Noble, "Muslims in the Philippines and Thailand", in Ethnic Conflict in International Relations, edited by Astri Suhrke and Lela G. Noble, (New York, NY: Praeger Publishers, 1977), 184.

${ }^{29}$ Following the 1973 war in Mindanao, both Saudi Arabia and Iran briefly suspended exports of oil to the Philippines to show their support for the $M N L F$

${ }^{30}$ W. K. Che Man, 79.

${ }^{31}$ Peter Gordong Gowing, Muslim Filipinos, 197.

${ }^{32}$ Cesar Villanueva and George Aguilar, “The Reintegration of the Moro National Liberation Front in Mindanao”, Center for International Cooperation and Security, (2008): 5.

${ }^{33}$ Lela G. Noble, "The Moro National Liberation Front," Pacific Affairs, vol.49, no.3 (1976): 413.

${ }^{34}$ Manifesto of Moro National Liberation Front on Declaration of Independence, Paragraph 4, number 4.

35 John Remollo Petalcorin, "About the Moro National Liberation Front", <http://bangsamoromnlf.blogspot.com/2011/01/aboutbangsamoro-mnlf.html> (accessed 5th January 2012).

${ }^{36}$ Manifesto of Moro National Liberation Front on the "Establishment of the Bangsa Moro Republic", Bangsa Moro Homeland, $28^{\text {th }}$ April 1974.

${ }^{37}$ Resolution No. 18 of the Political Committee at the Fifth Islamic Conference of Foreign Ministers, held at Kuala Lumpur, June 21-25, 1974. 
but just the same, we had to accept it otherwise, the result would be bad - isolation - so we had to look for a solution within the parameters of an autonomous government. ${ }^{38}$

During the first formal negotiation between the Philippine government and the MNLF in 1975, the OIC issued Resolution No. 10 to note the satisfaction of the government and the MNLF to establish a real Muslim autonomy, comprising the areas of Mindanao, Basilan, Sulu, and Palawan. ${ }^{39}$ In barely a year, and after a series of negotiations, the Tripoli Agreement was signed by both Parties, with the participation of the Quadripartite Ministerial Commission members and the Secretary General of the Islamic Conference, on December 23, 1976 in the City of Tripoli, Libya.

The first provision in the agreement is the "establishment of autonomy in the Southern Philippines within the realm of the sovereignty and territorial integrity of the Republic of the Philippines." 40 The Agreement identified the areas of Muslim autonomy, namely: Basilan, Sulu, Tawi-Tawi, Zamboanga del Sur, Zamboanga del Norte, North Cotabato, Maguindanao, Sultan Kudarat, Lanao del Norte, Lanao del Sur, Davao del Sur, South Cotabato, Palawan, and all the cities and villages situated within those thirteen above-mentioned provinces. Additionally, the Philippine government agreed that the Muslims would set up their own courts that would implement the Islamic Sharī'ah laws; schools, colleges and universities; and administrative systems in compliance with the objectives of the autonomy and its institutions. Furthermore, the authorities of autonomy would have economic and financial systems; special Regional Security Forces; Legislative Assembly; and Executive Council. Mines and mineral resources fall within the competence of the Central Government, though a reasonable percentage will be given to the Moro autonomy. Above all, the Agreement stated that the Bangsamoro would be given a right of representation and participation in the Central Government and in all other organs of the state. ${ }^{41}$

One should note the tone of the agreement. It clearly stipulated the word 'right' - not 'privilege' - to connote that the Muslims would be guaranteed a specific quota in the Central Government. The Muslims would have their representation in all branches and departments of the national government, including the national assembly, foreign services, Supreme Court and Court of Appeals, all branches of the Armed Forces of the Philippines (AFP), the Cabinet, the National Advisory Council, the National Security Council, and so forth.

This euphoric agreement, however, remained only a piece of paper. President Marcos derailed the correct implementation of the agreement. In 1976, Marcos issued Presidential Decree No. $1628^{42}$ declaring autonomy in the areas of Region IX and Region XII, which comprise the thirteen provinces. Under this Decree, plebiscite-referendum should be conducted within these areas to get the consent of the majority. This became a contentious issue as there was no reference of plebiscite-referendum from the Tripoli Agreement. According to Misuari, this particular provision was a trick by the government for it knew that Muslims were not majority in these areas. The possibility of winning was therefore very slim.

The population of these thirteen provinces at that time was around 6 million, and Muslims were estimated to be only half. Besides, the Muslims were only in absolute majority in the provinces of Lanao del Sur, Sulu, Tawi-Tawi, Basilan, and North Cotabato. The other provinces, such as Lanao del Norte, Maguindanao, and Sultan Kudarat, had less than 50 per cent Muslims, and only about 20 per cent in Zamboanga del Norte, Zamboanga del Sur, South Cotabato, Davao del Sur, and Palawan. ${ }^{43}$

Misuari declared to boycott the plebiscite-referendum, but the government ignored it and conducted the plebiscite on April 17, 1977. As expected, the result was a big blow to the MNLF's demand as it was totally rejected by most of those provinces, most especially the Christian-dominated areas. Only the provinces of Lanao del Sur, Sulu, Tawi-Tawi, Basilan, and Maguindanao voted for the autonomy. This result became the foundation of what is now known as the Autonomous Region in Muslim Mindanao (ARMM). All those agreed points in the Tripoli Agreement were almost not included in the ARMM. The scope areas were reduced from thirteen to only five provinces; and until now the government has not implemented those provisions about the genuine autonomy, the regional-internal army, the Sharī'ah court, the educational system, and the representation of the Muslims in the central government. The ARMM today is considered by no less than the Supreme Court of the Philippines as bogus autonomy for almost everything is still controlled by the national government. ${ }^{44} \mathrm{ARMM}$ is only given some administrative powers, not to make its own policies.

\footnotetext{
${ }^{38}$ Marites D. Vitug \& Glenda M. Gloria, 31.

${ }^{39}$ Resolution No. 10 of the Political Committee at the Sixth Islamic Conference of Foreign Ministers, held in Jeddah, $12-15$ July 1975.

${ }^{40}$ Agreement between the Government of the Republic of the Philippines and the Moro National Liberation Front with the Participation of the Quadripartite Ministerial Commission Members of the Islamic Conference and the Secretary General of the Organization of the Islamic Conference, Tripoli, 23 December 1976.

${ }^{41}$ Ibid.

${ }^{42}$ Presidential Decree No. 1628 of 1976 - Implementing the Organization of the Sangguniang Pampook and the Lupong Tagapagpaganap ng Pook in Region IX and Region XII and for other Purposes, < http://www.lawphil.net/statutes/presdecs/pd1979/pd_1618_1979.html > (accessed 11 September 2012).

${ }^{43}$ Cesar Adib Majul, 74.

${ }^{44}$ Maradika, "Supreme Court rules with finality: ARMM is not Autonomous", 7 November 2011, 1.
} 
As a result, hostilities erupted once more in Mindanao until the fall of the Marcos regime. When the new government came, it renewed the negotiation with the MNLF and it was in 1996, during the time of Fidel Ramos, that Misuari signed again the so-called "Final Peace Agreement", with the culmination of accepting the position of regional governor in the ARMM. Arguably, Misuari seemed to have backed into the fold of the government.

Now, the MNLF leadership seems to have fragmented and lost its support from the masses, although their commanders have denied it. According to Commander Narra, the MNLF vice-chief of staff, the organization has still a membership of about a million. ${ }^{45}$ Nonetheless, the reality on the ground appears to be contrary to the claim. MNLF today seems to be no longer a force for the government to reckon with because most of its mujähideen were integrated into the Philippine Army (PA) and the Philippine National Police (PNP). ${ }^{46}$ Furthermore, most of the MNLF founders lost their confidence on Misuari's leadership that eventually resulted to the breakup of the organization into many factions. ${ }^{47}$ For one reason or another, Misuari failed to fulfil his promises and campaigns during the height of war; or at least failed to meet the expectations of the Bangsamoro people when he was in power. This led to the erosion of support among the Bangsamoro people.

\section{Moro Islamic Liberation Front (MILF)}

Moro Islamic Liberation Front started as a breakaway group from the MNLF. During the early period of the struggle, Salamat Hashim, the founder and ideologue of the movement, was the MNLF vice-chairman and the chief for foreign affairs. The two leaders, Hashim and Misuari, had worked together very closely. Hashim even helped Misuari to get the post of chairmanship. ${ }^{48}$ However, due to differences of ideology and leadership style ${ }^{49}$ the two leaders began to disagree on almost all issues. Hashim started to question and disagree on issues and decisions that he thought were un-Islamic. Misuari, on his side, began deciding matters without consulting Hashim, and in most cases, Hashim was not even invited to attend major sessions of the Central Committee. Nonetheless, this internal strife was confined only to the high-ranking members of the group.

It was on September 21, 1977, right after the collapse of the GRP-MNLF peace talks in Manila, when the public knew of the disenchantment between the two leaders. All the 57 leading officers of the Kutawato Revolutionary Committee (KRC), the biggest single unit in the entire MNLF in terms of numbers and territorial jurisdiction, signed a petition addressed to the OIC and the Muslim World League (MWL) calling for the ousting of Nur Misuari as Chairman, and Salamat Hashim be recognized as the new Chair. ${ }^{50}$ Many more petitions from Cotabato, Lanao, Zamboanga del Sur, and Davao, were forwarded to the OIC and MWL.

Subsequently, Hashim announced his "Instrument of Takeover" on December 24, 1977, to finally declare his chairmanship. ${ }^{51}$ Hashim justified his takeover by the following:

The MNLF leadership was being manipulated away from its Islamic basis, methodologies and objectives and fast evolving towards a Marxist-Maoist orientation.

...The Central Committee has evolved into a mysterious, exclusive, secretive and monolithic body whose policies, plans and decisions - political financial, and/or strategic - became an exclusive preserve of Nur Misuari.

This mysterious, exclusive and arrogant nature of the MNLF leadership resulted in confusion, suspicion and disappointments among members and mujahideen in the field, resulting in the loss to the cause of a great number of freedom fighters. ${ }^{52}$

\footnotetext{
${ }^{45}$ Narra Abdul Jabbar Jialil, vice-chief of staff of Bangsamoro Armed Forces - Moro National Liberation Front, interview by the author, Marawi City, 7 February 2012.

${ }^{46}$ 5,700 of the MNLF-Bangsa Moro Army integrated to the Armed Forces of the Philippines, and another 2,500 to the Philippine National Police.

${ }^{47}$ Among those are: Salamat Hashim, the former MNLF Vice-Chairman, broke away and founded the MILF; Melham Alam, the former MNLF Chief of Staff, broke away and founded the Islamic Command Council (ICC); Muslimin Sema, the former MNLF Secretary General, also broke away and declared himself as the leader of the 'Council of 15'. Sema was also declared by the MNLF Central Committee as the new Chairman in 2008. Additionally, Misuari had been under house arrest from 2001 to 2008. He had only gone out after the court allowed him to post the bail. Furthermore, Misuari seemed to lose his support from the ground for he lost his gubernatorial candidacy thrice, consecutively.

${ }^{48}$ Salah Jubair, 154.

${ }^{49}$ The two leaders have different educational background. Salamat Hashim finished his Islamic studies at Al-Azhar University, Egypt. This particular background shaped Hashim to become an Islamic-oriented. For Nur Misuari, he is usually referred to as secular-oriented for he finished his study in Political Science at the University of the Philippines. As shown from the discussion above, the two leaders have different goals should their organization succeed. Nur Misuari's goal is to liberate the Moroland from the yoke of oppression with democracy-type of governance. To some account, it was reported that Misuari had aligned himself with the communists in the country. For Hashim, it is not only to liberate the Moroland and have freedom; rather what is more important is to have an Islamic state where Sharia can be the rule. This is how the two leaders were identified based on their orientation and goal. For the leadership style, Misuari was said to have monopolized the decision-making in the MNLF, while Hashim was following the collective-type of decision-making in the MILF.

${ }^{50}$ Salah Jubair, 154

${ }^{51}$ Michael O. Mastura, Bangsamoro Quest: The Birth of the Moro Islamic Liberation Front, (Malaysia: SEACSN and REPUSM, 2012 ), 39.

${ }^{52}$ Letter of Salamat Hashim to OIC Secretary General Ahmadou Karim Gaye dated December 23, 1977.
} 
Misuari categorically refused to recognize the takeover, and accused Hashim of "treachery", "incompetence", and "insubordination". He even stripped off all his MNLF posts and declared him as persona non grata. ${ }^{53}$ The attempt of the OIC and MWL to settle the differences had no substantive result. The Secretary General of the MWL also mediated and presided over the meeting between the two leaders in order to come up with a common platform where they could work together again, but this effort achieved nothing. The two leaders finally separated, and each followed their ideologies and principles.

In March 1984, the Central Committee of the new leadership officially declared itself a separate organization. The new organization, now called as Moro Islamic Liberation Front (MILF), emphasized Islām as the official ideology that would guide all the affairs and activities of the organization. As Hashim declared publicly, and enunciated in his widely disseminated book entitled The Bangsamoro Mujahid: His Objectives and Responsibilities that "the ultimate aim of our Jihad is to make supreme the Word of Allah." ${ }^{\text {"54 }}$ This means, as he elaborated, Muslims must subordinate every aspect of their worldly wishes and desires to the Word of Allāh, including in the matter of adopting a political system, as well as legal, economic, educational and social systems. Making the Word of Allāh supreme is the establishment of a true Muslim community, a genuine Islamic system of government and the application of a real Islamic way of life. ${ }^{55}$

Hashim's ideology is influenced by renowned Muslim reformer in Egypt, Such as Hassan al Banna and Syed Qutb. In fact, Syed Qutb's Milestone shaped his Islamic outlook and political beliefs. ${ }^{56}$ Hashim had studied in Al-Azhar University under the scholarship of the Egyptian government under Gamal Abdul Nasser. Among his contemporaries in the university were Burhanuddin Rabbani and Abdul Rasul Sayyaf who became the leaders of Afghanistan's anti-Soviet mujāhideen ${ }^{57}$ As a founder of the Islamist movement, Hashim was considered as a revolutionary leader who wanted to liberate the Bangsamoro people from the yoke of oppression, and an Islamic revivalist who emphasized the importance of Islām as a way of life. For his supporters, Hashim was a reformer that can be compared to the popular reformers in the Muslim world like Omar bin Abdul Aziz, Imām Shafi'e and Ibn Taimiyyah. ${ }^{58}$

Paramount to his vision was the establishment of an Islamic government, which he considered as one of the requirements in the perfection of the Muslim's 'ibadāh (devotion) to Allāh. According to him, 'ibadāh is not only limited to the basic tenets of Islām - the five pillars of Islām. It also includes the political affairs of Man, business transactions, social relations, education, culture, and all other aspects of life. ${ }^{59}$ Hence, everything in the society must be governed according to the Islamic teachings.

MILF is not only a liberation movement that propagates armed-struggle. It is an organization committed to revive Islām in all aspects of life in Mindanao. Hashim outlined "four-point" programs, with a time frame of 50 years, to realize his vision. These are: Islamization of the Bangsamoro people in all aspects of life; strengthening and improvement of the organizational and administrative capability; military build-up; and self-reliance. These four points will be discussed in detail in the subsequent pages.

\section{Islamization}

The process of the Islamization is not directed to the Christians in Mindanao. It primarily concerns the Muslims at large who tend to increase in number, but not in faith. Moros, with due respect to others, are now in the trend of becoming secular who want to separate religion from the state. Hashim wanted to eliminate this kind of trend and called on the Moros to follow Islām more faithfully and reform their lives, homes and society. He wanted them to strictly adhere to tawhìd (monotheism) and put Allāh in the centre of their private and public lives. He even wanted the political leaders to ensure that Islām became the foundation and basis of any political action. As Joseph Liow ${ }^{60}$ detailed:

Hashim proposed that it was through da'wah and jihad that the MILF Islāmization agenda, which comprised of the transformation of every Muslim in MILF into 'a true and real Muslim whose beliefs... and his entire life is in conformity with the teachings of Islam derived from the Qur'an and Sunnah', of every MILF home into 'real Islamic homes where

\footnotetext{
53 Salah Jubair, 155.

${ }^{54}$ Salamat Hashim, The Bangsamoro Mujahid: His Objectives and Responsibilities, (Mindanao: Bangsamoro Publications, 1985 ), 4.

${ }^{55}$ Salamat Hashim, 8-9.

${ }^{56}$ Abhoud Syed Mansur Lingga, "The Political Thought of Salamat Hashim”, (M.A. Thesis, University of the Philippines, 1995$), 26$.

${ }^{57}$ International Crisis Group, "Southern Philippines Backgrounder: Terrorism and the Peace Process," International Crisis Group Asai Report No. 80, 13 July 2004, 3.

${ }^{58}$ Francisco Cruz Jr., "Morojihad and the Islamic Vision of Ustadz Salamat Hashim: Understanding MILF's Politico-Religious Ideology", Philippine Institute for Political Violence and Terrorism Research, (August 2008): 1.

${ }^{59}$ Francisco Cruz Jr., 7-8.

${ }^{60}$ Joseph Chinyong Liow is a professor of comparative and international politics and an associate dean at the S. Rajaratnam School of International Studies, Nanyang Technological University, Singapore. His research interests encompass Muslim politics in Southeast Asia and the international politics of the Asia-Pacific region.
} 
the teachings of the Qur'an and Sunnah prevail', and of community into 'a true Islamic one governed by the Shari'ah' would be realized. ${ }^{61}$

Hashim reiterated the needs of having God-fearing leaders in order for the community to be Islamized. He wanted to reinstate the practice during the time of the Prophet (saw) where the affairs of the government and practice of the faith were inseparable. As he declared, "practicing Islam without governmental sanction is a truncated version of the faith and, therefore, un-Islamic. A government not founded on Islamic principles (Qur'ān and Sunnah) is unquestionably un-Islamic". ${ }^{62}$ That is why, Hashim urged the Bangsamoro people not to limit their 'ibadāh to the performance of the five pillars of Islām only. He encouraged them to be involved in the political, social, cultural, and economic affairs in the society. He asserted that active involvement and support to the Bangsamoro struggle is an 'ibadāh or a service to Allāh (swt). ${ }^{63}$

As part of the Islamization process, the MILF introduced various programs in order to promote awareness and practice of Islamic teachings. These various programs were initially introduced to the MILF members to serve as a model to the public. The two biggest MILF camps, the Camp Abubakar and Camp Bushra, have always been referred as "Dārussalām" (abode of peace) and "Dārul İmān" (abode of faith) because of their adherence to the Islamic way of life.

Inside Camp Abubakar, before it was captured by the government forces in 2000, observers would feel its difference from the outside community. Islamic practices and injunctions were implemented inside the Camp. Named after the first successor of the Prophet (saw), Camp Abubakar was the general headquarters of the MILF and the centre of power and authority of the organization. It was also the symbol of the Islamic revolution that they were waging. Hashim made Camp Abubakar like an entire community with religious, social, economic, and military structures. There were schools, madrasah, mosques, Sharī'ah courts, and multi-purpose cooperatives that would cater to the needs of the people inside the camp. In other words, Camp Abubakar was more than just a military camp.

In Camp Bushra, the stronghold of the vice-chairman Aleem Abdul Aziz Mimbantas, Islamic practices have also been observed. A madrasah called Ma'had Palestine has been there since the founding of the camp. Named as such to constantly remind the local residents and the mujähideen about their obligations and supplications towards their Palestinian brethren, the main purpose of the madrasah is to give Islamic education to the locals, especially the children and families of the mujāhideen. Mimbantas underscored that this is to "give an opportunity to the people who are deprived of basic education, either Islamic or Western, to at least learn how to read and write." ${ }^{64}$ According to him, they ask their 'ustäz (Arabic teacher) to teach those children. Most of them gave one day a week, but some devotedly gave their full time to the madrasah. As a result, MILF have produced students who are really committed to the Islamic cause and to the organization. At one point of time, MILF had managed to send few students to study abroad.

Furthermore, the MILF Islamization program includes the setting up of Shari' $a h$ Court inside the camps. Muslim scholars who earned the degree of Islamic Jurisprudence, Fiqh, and Usül al Fiqh were given the task of handling cases. Shari 'ah lawyers were in-charge of looking into the details of every case that the people submit to the MILF, instead of going to the government-run courts. Under Philippine laws, the Shari 'ah court covers only domestic and family issues. ${ }^{65}$ MILF disregarded this and expanded the court's domain to other offenses, especially to the criminal ones.

During the heyday of the MILF in Camp Abubakar, numerous cases of all kinds were submitted to its Shari' 'ah court - ranging from killing to stealing. Punishments were given based on the committed crimes and offences. Among the punishments were the 100 lashes for fornication between an unmarried man and woman, ${ }^{66}$ hard labour for those who steal to pay their debts, imprisonment for recidivists, and even executions for murderers. According to the MILF, all these punishments are based from the injunctions of the Qur'ān and Sunnah. The last reported execution in Camp Abubakar was in $1985,{ }^{67}$ and the most recent one that had taken place outside the camp was in 1997. According to Mimbantas, "we decided for the execution to take place outside Camp Bushra in order to show the growing influence of the MILF, and let many people as possible to witness the execution." The main purpose of this was to serve as a deterrence mechanism for other people not to

\footnotetext{
${ }^{61}$ Joseph Chinyong Liow, "Muslim Resistance in Southern Thaniland and Southern Philippines: Religion, Ideology, and Politics", EastWest Center Washington, Policy Studies 24 (2006): 15.

${ }^{62}$ Salamat Hashim, 1.

${ }^{63}$ Lualhati M. Abreu, "The Bangsamoro Ancestral Domain: The Bangsamoro Continuing Past Anchored on Customary Adat and Islamic Thinking", in The Mindanao Conflict, edited by Kamaruzaman Askandar and Ayesah Abubakar (Malaysia: The Southeast Asian Conflict Studies Network Publications, 2005), 110.

${ }^{64}$ Aleem Abdul Aziz Mimbantas, Vice-Chairman for Military Affairs, Central Committee of the Moro Islamic Liberation Front, interview by the author, Camp Bushra, $28^{\text {th }}$ January 2012.

${ }^{65}$ See Hamid Aminoddin Barra, The Code of Muslim Personal Law: A Study of Islamic Law in the Philippines, (Marawi City: Mindanao State University, 1988).

${ }^{66}$ Marites D. Vitug \& Glenda M. Gloria, 109

${ }^{67}$ Ibid.
} 
do the same crime. In Islām, he added, "The aim is to achieve peace and order in the community, not really the execution. It may be harsh in the eyes of the common people, but this is merely implementing what Allāh has ordered us to do. The Qur'ān and Sunnah are very clear about this, so we should not doubt and compromise even a little."

The Sharī'ah court is still operational to some other MILF-controlled areas. Aside from Camp Abubakar and Camp Bushra, the MILF leadership recently approved the North Western Mindanao Front Mobile Sharī'ah Court. This court is under commander Abdullah Macapaar, who is given the mandate to continue operations against individuals who have criminal and unlawful records. Known as Commander Bravo, he explains that this court is "just a branch of the MILF Sharī'ah Court that implements all Islamic injunctions. We search for people who have criminal records, who do unlawful sexual intercourse, who are involved in drugs or any kind of gambling, who drink alcohol, and who do any other deceitful activities." ${ }^{.68}$ Any activities that contradict the Islamic teachings should be stopped, though the operations depend on their capability. Bravo made it clear that "we have to accept the reality that we are not yet completely independent, thus, our operations are only confined to some specific areas."

Qur'ān and the Sunnah are the basis in giving reprimands. The mobile Sharī'ah court is equipped and composed of 20 competent and learned people who are in charge of giving verdict on every cases. "In every different cases, we have to look back to the Qur'ān and Sunnah," explained by one of the 20-learned people. Nonetheless, those learned-people are given full authority to come up with verdict based on their own intellect and reason if the Qur'ān and Sunnah are not clear about this. There are some circumstances that they usually take into considerations. As Bravo further explained, "the punishments were not directly imposed to the first offenders. We consider the reality in our society. Warnings are primarily given; and we only carry out punishments if those warnings are ignored. Detention camps are also available in order to detain the suspects while waiting for the verdict."

MILF's Sharī'ah court does not confine its rulings to crime-related matters only. Islamic injunctions are also observed in other aspects of life. For example, inside the two camps, women are not allowed to be in public if they are not dressed decently - loose clothes that cover their body, with veils over their heads; malefemale contact between non-immediate relatives is strictly prohibited; business transactions are regulated to make sure that $r i b \bar{a}^{69}$ and other deceitful transactions do not take place; prices in the market are monitored to avoid overpricing; weighing scales and tape measurements are checked to avoid cheating; and most importantly, foods and beverages are screened to avoid non-haläl foods and alcoholic drinks. The locals had always referred to Camp Abubakar as Dārussalām and to Camp Bushra as Dārul İmān for the social justice, peace and order they provided.

Drug and gambling operations were also part of the MILF Islamization programs. ${ }^{70}$ When drug trafficking became rampant, and drug addiction among the Moros reached an alarming level, MILF leadership issued a stern warning to all drug pushers and users to stop the vice. Not long after the warning, MILF mobilized its own special team and conducted operations against them. It was reported that MILF was very active in drug operations in Marawi city, Lanao del Sur, in the late 1990s.

More recently, in 2011, the MILF carried out similar operations against killers, drug traffickers and gamblers in different municipalities. Dubbed as "Bismillah," the operation had managed to capture few serial killers, prominent drug lords, people involved in various kinds of gambling (including cock-fighting), and it managed to destroy places where those gambling and cock-fighting were taking place. ${ }^{71}$ The most significant part of this operation, as another commander commented, ${ }^{72}$ was that it focused more in Masiu, the birthplace of the vice-chairman Mimbantas. This was to show to the people the sincerity of the MILF leadership in curbing drugs and other gambling-related activities in the area.

As part of the remedy, MILF constructed its own rehabilitation centres in Camp Abubakar and Camp Bushra in order for the prisoners to have rehabilitation and orientation classes. Inside the centre, the prisoners are given $d a$ 'wah and education. Various Islamic practices, such as reading the Qur'ān and fasting every Mondays and Thursdays, are also part of the rehabilitation program.

\section{Strengthening the Organization}

Unity is one of the basic requirements for any organization to achieve victory. Islamic teachings affirm this for an Islamic call is not an individual task, rather a collective duty and obligation. History attests that during the time of the Prophet (saw), priority was given to the matter of strengthening the organization for the Prophet (saw) knew the futility of launching a fight with disorganized group, much less by an individual

\footnotetext{
${ }^{68}$ Abdullah Macapaar, the Front Commander of North Western Mindanao Front, interview by the author, Wato, $1^{\text {st }}$ February 2012.

${ }^{69}$ Riba is commonly defined as interest-based transaction.

${ }^{70}$ Al Haj Murad, Jihad in Defense of Islam and the Bangsamoro People, (Mindanao: Agency for Youth Affairs - MILF, 2006), 46.

${ }^{71}$ Bin Masdidah Mimbantas, $2^{\text {nd }}$ in command of the Bismillah Operation, interview by the author, Camp Bushra, $28^{\text {th }}$ January 2012

${ }^{72}$ Mitch Mimbantas, accomplice of the Bismillah Operation, interview by the author, Camp Bushra, $28^{\text {th }}$ January 2012.
} 
struggle. ${ }^{73}$ Emulating the Prophet (saw), Hashim wanted to have a strong organization that is capable of enduring all hardships. He maintained that the organization must be founded on shüra (consultation), justice and equality for, according to him, "justice is the natural consequence of shura and equality is the natural consequence of justice. There will be no equality if there is no justice, and there will be no justice unless the affairs of men are conducted through consultation." 74

Hashim situated that the MILF would become a mass-based organization that could represent the various ethnic groups in Mindanao. He made sure that MILF's Central Committee - the committee that is responsible for the day-to-day affairs of the organization - would be composed of different ethnic groups and sectors. Professionals, businessmen, politicians, and youths from different parts of Mindanao have their representatives in the Committee.

The MILF maintains its popular support from the areas of Maguindanao, Lanao del Sur, Lanao del Norte, North Cotabato, and Basilan. ${ }^{75}$ On October 5-7, 1986, the MILF held a military consultative assembly in which more than one million people from all over Mindanao showed up, and almost eighty thousand of them were armed with various kinds of weapons. ${ }^{76}$ Additionally, in 2005, the MILF general consultation had managed to gather more than three million supporters, although the media put it into several hundred thousand. Even then, it was emphasized that "this was more than the MNLF could ever muster, making the MILF by far the largest and most powerful resistance group operating in southern Philippines today.",77

Another proof of the MILF's mass appeal can be observed in the following remark:

The Armed Forces of the Philippines [AFP] faces serious difficulty in gathering information from the MILF controlled areas because most of the local population refuses to cooperate with them. The mass support enjoyed by MILF is largely due to its emphasis on Islamic symbols and substance of liberation movement. ${ }^{78}$

Apart from being a mass-based organization, the MILF ensures the stability of the organization by dividing the key executive positions to the two big ethnic groups: Maguindanaon and Maranao. Since Chairman Hashim is Maguindanaon, one of his deputies is given to Abdul Aziz Mimbantas, a Maranao and al-Azhar graduate, who is in-charge of implementing the Qur'ān in their own controlled areas. One of the very remarkable test to the unity of the MILF was the smooth succession of chairmanship after the sudden death of Hashim. ${ }^{79}$ Despite of having three deputies, MILF did not have bumpy succession mainly because of the greater unity in the organization. Al Haj Murad was wholeheartedly given the post without any challenge from the other two deputies. As Mimbantas comments, "this is perhaps the only revolutionary organization in the world that has such a smooth succession. Instead of fighting as to who should succeed the chairmanship, the three deputies were all with the idea of putting someone to the post other than himself." Chairman Murad himself admitted that chairmanship was initially offered to Mimbantas, but he sincerely refused the offer. ${ }^{80}$

\section{Military Build-Up}

MILF focuses equal attention to its military capabilities. According to Hashim, military build-up is very important to repulse any aggression against Islām. He strictly adhered to the Islamic principle that when a Muslim community is persecuted, oppressed, or denied liberty and freedom to perform its duties to Allāh, then armed-struggle became an obligatory duty to each and every Muslim. ${ }^{81}$

Prior to his demise, Hashim established the Abdulrahman Bedis Memorial Military Academy (ABMMA) for the new recruits to undertake a series of physical and spiritual training before joining the ranks. In addition to the physical training, such as mastering obstacle courses, marching drills and firing several weapons, series of Islamic lectures for the trainees' were conducted to enhance their understanding on Islam in general and jihad in particular. As Benjie Midtimbang, one of the training directors had reportedly said:

We are not strict with educational background, only their loyalty to the faith, the cause, and their sincerity. We put more stress on Islamic spiritual training rather than on the physical

\footnotetext{
${ }^{73}$ Salamat Hashim, 24-25.

${ }^{74}$ Francisco Cruz Jr., 8.

${ }^{75}$ Peter Chalk, "Separatism and Southeast Asia: The Islamic Factor in Southern Thailand, Mindanao and Ache", Studies in Conflict and Terrorism, vol.24 (2001): 241-269.

${ }^{76}$ Ismael G. Kulat, GRP-MILF peace talks: Its implication to the Bangsamoro Struggle for Right to Self-Determination (Cotabato City: Consortium of Bangsamoro Civil Society, Inc., n.d.), 6.

77 Joseph Chinyong Liow, 13.

78 Shamsuddin L. Taya, "The Political Strategies of the Moro Islamic Liberation Front for Self-Determination in the Philippines," Intellectual Discourse, vol. 15 , no. 1 (2007): 66.

79 Salamat Hashim died on $13^{\text {th }}$ July 2003 at Camp Bushra due to sudden cardiac arrest. He was subsequently replaced by the current chairman, Al Haj Murad Ebrahim.

${ }^{80}$ Speech of Al Haj Murad Ibrahim during the death of the late vice-chairman Aleem Aziz Mimbantas, Camp Darapanan, Maguindanao, $28^{\text {th }}$ June 2012

${ }^{81}$ Salamat Hashim, 12-13.
} 
and mental aspects. Fasting twice a week is optional for the trainees but hour-long midnight prayers are a must. ${ }^{82}$

After the demise of Hashim, the new leadership decided to rename and relocate the military academy in honour of him. Named after Hashim, Salamat Hashim Islamic Memorial Military Academy (SHIMMA) is now relocated to Camp Bushra - where Hashim died - and is now in charge of training the military forces of the Front. SHIMMA has now three-long-month training, and it is divided into two phases. According to Oshama Bin Ali, the director general of SHIMMA, the extent and qualifications of the new academy are expanded and enhanced. In addition to the spiritual aspects and the sincerity to the organization, high educational background of the trainees became a must. ${ }^{83}$ Further requirements are to be free of criminal records or no case filed against him/her in any of the MILF courts, at least 5 years in the organization, have completed the basic military training by the Bangsamoro Islamic Armed Forces (BIAF), and must have recommendation from his/her base commander. Furthermore, the trainees should also have memorized at least a few Qur'ānic chapters.

All these requirements and qualifications, most especially the spiritual and moral-related requirements, are all in accordance with Hashim's vision. As he justified, spiritual or moral superiority is more important than physical or material strength, for the fact that the former does not depend on the availability of all factors that sustain the physical existence, such as food, clothing, air, and other material needs ${ }^{84}$ Spiritual strength draws its energy and force from a source invulnerable to physical destruction. "When an army is defeated militarily", Hashim stressed, "it can still rebuild, reorganize and recoil into an even greater attack. But when an army is defeated morally and spiritually, all the material weapons at its command become useless pieces of hardware and it will be permanently subdued by the victor. ${ }^{\prime 85}$ Simply stated, military defeat is only temporary while moral defeat is permanent.

When the former academy was first set up in 1987, the organization claimed to have trained more than 100,000 mujähideen, with about $70 \%$ of them were armed. International Crisis Group specifically reported that the MILF has trained around 122,000 men and they could be mobilized to back up the Movement's 10,000 to 15,000 armed regulars. ${ }^{86}$ Since the foundation of SHIMMA in 2004, it has trained 533 male and female officers in 5 batches. ${ }^{87}$ Apart from the graduates of these two academies, the MILF has also more than 500 Afghantrained cadre officers who served as training directors and heads of the Special Forces. Cadre Officer Lotfi, one of the leading Afghan-trained officers, said that "During the time of ustāz Salamat Hashim, the MILF leadership had a strong connection with the Afghan mujähideen. Thus, the MILF leadership decided to bring some of its trusted men in order to be trained for months and years in all kinds of war-related materials and activities." ${ }^{\prime 88}$

To make the academy complete, MILF built a modest arms manufacturing centre. A senior MILF official revealed in 1997 that the group has a "small" and "modest" arms factory that could supply M79 grenade launchers, pistols, improvised M14 automatic rifles copied from the US Garand rifle, mortars $60 \mathrm{~mm}$ and $81 \mathrm{~mm}$ ) and even anti-tank weapons. ${ }^{89}$ In other sources, it is revealed that the MILF has a huge arsenal of weapons that, aside from the normal AK47, M16, and M14 rifles, includes Russian made RPG-2 rocket propelled grenade launchers, mortars, machineguns, and allegedly a US-made Stinger anti-aircraft missile.

The MILF chairman and the vice-chairman for military affairs confirmed these reports. During an interview with MILF Chairman Al Haj Murad Ibrahim, ${ }^{90}$ he proudly declared that the MILF has been running its own 'modest' arms manufacturing centre inside its vast jungle. Later on, an interview with vice-chairman Mimbantas further revealed that most of the RPG2 that they supply to their fighters are locally made from their own arms manufacturing centre. Ammunitions of almost all kinds are also produced at the centre. Thus, according to both, MILF can sustain long fight against the government forces. On top of all these confession, the low-ranking elements of BIAF clandestinely, yet beamingly, exhibited to the researcher the newest and strongest sophisticated RPG-7 tank smasher and the Pearl Harbour vintage anti-aircraft of the organization. With all these sophisticated weapons, one can almost be certain that the MILF has bought and smuggled weapons from other countries.

\section{Self-Reliance}

\footnotetext{
${ }^{82}$ Marites D. Vitug \& Glenda M. Gloria, 110.

${ }^{83}$ Oshama Bin Ali, Director General of Salamat Hashim Islamic Memorial Military Academy (SHIMMA), interview by the author, Dārul Imān, satellite camp of Camp Bushra, $29^{\text {th }}$ January 2012.

${ }^{84}$ Salamat Hashim, 41-42.

${ }^{85}$ Ibid.

${ }^{86}$ International Crisis Group, 4-5.

${ }^{87}$ SHIMMA printed documents, provided by Oshama bin Ali, Director General of the Academy.

${ }^{88}$ Lotfi, one of the Afghan-trained Cadre Officers, interview by the author, Camp Bushra, Butig, 29 January 2011.

${ }^{89}$ Soliman, M. Santos, Jr. \& Paz Verdades M. Santos, Primed and Purposeful: Armed Groups and Human Security Efforts in the Philippines, (Switzerland: Small Arms Survey, 2010), 355-356.

${ }^{90}$ Al Haj Murad Ibrahim, the Chairman of Moro Islamic Liberation Front, interview by the author, Camp Darapanan, Maguindanao, 6 February 2012.
} 
Since its inception, MILF has been involved in socio-economic developments in order to become selfreliant. The members of the organization are encouraged to involve themselves into all kinds of livelihood to sustain their personal and organizational needs. According to Chairman Murad, "this concept is the first and foremost concept that we thought to our members. The ultimate reason for this is to become not solely dependent on the monetary help coming from outside, most especially the Arab World, as was the MNLF case." "We encourage our members," Murad continued, "to seek any livelihood that would be suitable for them to sustain their personal and organizational needs."

Murad further explains that the reason why the vast numbers of their mujähideen are not permanently stationed in their various camps is to give them ample time to earn their livelihood. These jobs include farming, fishing, trading, teaching, and doing small and big businesses in the cities, including Manila. It all depends on the circumstances that provide suitable livelihood for every member. Some manage to be teachers, security guards, police officers, soldiers, or any other bureaucratic positions. "What we only restrict them from doing", Murad hastily clarifies, "is not to get involved in drug trafficking and other un-Islamic-related businesses and transactions."

This concept of financial self-reliance is succeeding to a greater extent, especially with the highranking officials of the MILF. For example, the late chairman Hashim was reported to have various investments in the Philippines; the late vice-chairman Mimbantas was a missionary of Libya's Islamic Call Society; the current chairman Murad has various businesses such as rice mills, restaurants, taxi-lending, and lodgings; and Ghazali Jaafar, the vice-chairman for political affairs, has his own farm and logging businesses. For the lowerranking members, the concept is also succeeding, though at a slower pace. Most of them are either involved in farming or fishing, or engage in small businesses. As Murad acknowledged, "only about $50 \%$ of our members have achieved the status of being self-reliant. The rest are either supported by relatives and family members or relying on donations." Hence, seeking donations from abroad is not completely ruled out. According to Jaafar:

We have not received funds from foreign countries with preconditions for military activity.

We have been receiving contributions from people of the world, some people in Saudi Arabia

and Middle East countries, but these moneys are given in sympathy for the Bangsamoro cause with no strings attached. ${ }^{91}$

All those donations were coming mostly from individual philanthropists in the Arab World. In addition to all these donations, the MILF tries some other avenues to generate more money. The most notable ones are the collection of Zakāh, Zakātul Fitr, Sadaqah, and remittances that come from the overseas Moro workers who are members of the United Overseas Bangsamoro. ${ }^{92}$ Reports reveal that MILF collects one million pesos monthly from about 27,000 Muslim contract workers in the Middle East, and receives about 1.5 million pesos a month from sadaqah. ${ }^{93}$ Further, the Zakätul Fitr that the MILF receives at the end of every Ramadann is also a considerable amount.

On top of these revenues and donations, MILF also makes use of the vast cultivable land inside its own territory. The area of Camp Abubakar, having almost 5,000 hectares, is good for various agricultural products. In 1998, a fruit nursery had been initiated through the MILF-controlled cooperatives, with the help of experts from the Central Mindanao Agriculture and Resources Research and Development consortium based in the University of Southern Mindanao. ${ }^{94}$ A solar-powered water pump was employed to help irrigate the farmlands and to cultivate the rice, fruit trees, and vegetables. Other hectares of the land served as a nursery for seedlings of durian, lanzones, mangosteen, and rambutan. ${ }^{95}$ In Camp Bushra, several thousands of hectares are also planted with banana, corn, cassava, coconut, and coffee. In some other camps, like Camp Abu Muthanna, the $114^{\text {th }}$ Base Command of MILF Western Front Command in Basilan, it was the base commander himself who planted various agricultural products, such as coconut, banana and durian. With the background of agricultural engineering, ${ }^{96}$ Musao Abubakar knows what plants and other agricultural products are more suitable to their own fertile land.

\section{THE ABU SAYYAF GROUP (ASG)}

Abdurajak Janjalani is the founder and ideologue of the new splinter group. He was once a strong supporter of Misuari during the early years of the revolution. However, he founded his own organization because he lost his confidence to the MNLF leadership. Often referred as ASG, Abu Sayyaf Group is somewhat the most misunderstood liberation movement in Mindanao. Most writers and journalists who wrote about the

\footnotetext{
${ }^{91}$ Soliman, M. Santos, Jr. \& Paz Verdades M. Santos, 349.

${ }_{92}^{2}$ Soliman, M. Santos, Jr. \& Paz Verdades M. Santos, 347.

${ }^{93}$ Francisco Cruz Jr., 10.

${ }_{94}^{94}$ Marites D. Vitug \& Glenda M. Gloria, 108.

${ }^{95}$ Ibid.

${ }^{96}$ Musao Abubakar, alias Mujahid, Commander of 114 Base Command of MILF Western Front, interview by the author, Camp Muthanna, Basilan, 2 February 2012.
} 
ASG pointed out that the group is either terrorist group, which has connection with al-Qaeda, or bandit group that operates kidnap-for-ransom activities. ${ }^{97}$ Authors like Soliman Santos, Jr. and Octavio Dinampo attested that ASG is hard to categorize as a rebel or agent or bandit or even as a terrorist group. ${ }^{98}$

Although the research does not overlook the possibility that the group may have connection with alQaeda, and that some of their members may have carried out such kidnap-for-ransom activities, this research is more on to emphasize the reason why these people had behaved such way. Despite of their radical approaches, there are still many people in their community who support the group. Only people who have not visited the communities where ASG has been active would believe that the group is fighting without direction. Impartial survey would reveal that ASG is firmly motivated by religious inclination. Abdurajak Janjalani was known in his hometown as a revered and respected $u s t \bar{a} z$.

In Tabuk, Isabela City, Janjalani's modest house is adjacently linked to an Islamic school. In this area, it is rare to find a person who does not hold Abdurajak very dearly. When he was alive, none of the local residents would dare to call his name without ascribing the word "ustäz", a title that is given to a person who is an Arabic/Islamic teacher. Even now that he already died and the government keeps on labelling him as terrorist, the people of Basilan do not call his name without directing him as shahid or martyr, a highest honour to those who died in the name of Allāh and His religion. As one local resident boldly said, "shahìd Jal (Janjalani) was the champion of defending Islām." 99 Another local resident nostalgically recalled the days when Janjalani was still alive and kept on lecturing about Islām in his adjacent Islamic school. "The local residents here were very happy to have him as he lectured the students for free. It was his conviction that the people would follow Islām completely, including jihād."

Contrary to the common perception, Janjalani was just like Misuari and Hashim who fought the government forces with the sole purpose of liberating the Muslim land, getting freedom, and most importantly making the Qur'ān and Sunnah supreme. What is perhaps new and uncommon to Janjalani's group was their emphasis on achieving the goal by whatever means, including violence. Nonetheless, for Janjalani and his comrades, it is a jihād fí sabìlillāh, or fighting in the name of Allāh, in which Islām does not only make it permissible, rather a direct injunction to the Muslims to defend Isläm and to fight against aggression and injustices. This is not violence as understood by the West.

Hence, it is a wrong perception to completely seclude ASG from MNLF and MILF. Janjalani and other founders of the group were dissatisfied members of the MNLF and MILF. ${ }^{100}$ The ASG is merely an alternative group in achieving the goal of what both the MNLF and MILF have been fighting for. As Janjalani argued, he founded the ASG as an alternative resistance group of Bangsamoros who were disappointed with the secular leaderships of the MNLF and the moderate Islamist position of the MILF. ${ }^{101}$ In his undated public proclamation, Janjalani explained what he called the "Four Basic Truths" about the ASG:

1. It is not to create another faction in the Muslim struggle, which would be against the teaching of Islām, especially the Quran, but to serve as a bridge and balance between the MILF and MNLF, whose revolutionary roles and leadership cannot be ignored or usurped;

2. Its ultimate goal is the establishment of a purely Islamic government, whose "nature, meaning, emblem and objective" are basic to peace;

3. Its advocacy of war is a necessity; for as long as capricious ambitions, oppression, and injustice exist, and arbitrary claims are imposed on the Muslims;

4. It believes that "war disturbs peace only for the attainment of the true and real objective of humanity - the establishment of justice and righteousness for all under the law of the noble Quran and the purified Sunnah." 102

The foundation of the ASG can be traced back to the time of jihädi movements in Afghanistan. The original name of the group is Al-Harakatul al-Islāmiya (which literally means the Islamic movement) ${ }^{103}$ that was

\footnotetext{
${ }^{97}$ See Zachary Abuza, Balik-Terrorism: The Return of the Abu Sayyaf; Romel C. Banlaoi, Al- Harakatul Al-Islamiyyah: Essays on the Abu Sayyaf Group; and Elegant Simon, The Return of Abu Sayyaf.

${ }_{98}$ Soliman M. Santos, Jr. and Octavio A. Dinampo, "Abu Sayyaf Reloaded: Rebels, Agents, Bandits, Terrorists (case study), in Primed and Purposeful: Armed Groups and Human Security Efforts in the Philippines, edited by Diana Rodriguez, (Geneva: Small Arms Survey, Graduate Institute of International Development Studies, 2010), 115.

${ }_{99}$ Interview with local residents, Tabuk, Isabela, Basilan, $2^{\text {nd }}-4^{\text {th }}$ February 2012.

${ }^{100}$ For more detailed analysis of the origin, evolution and dynamics of the ASG, see Rommel C. Banlaoi, Al Harakatul-Al Islamiyah: Essays on the Abu Sayyaf Group (Quezon City: Philippine Institute for Peace, Violence and Terrorism Research, 2009).

${ }^{101}$ Rommel C. Banlaoi, "Bangsamoroism and the Nexus of Identity Politics and Violent Extremism in the Southern Philippines. Presented at the International Workshop on "The Impact of Identity Politics on Violent Extremism" organized by the Centre of Excellence for National Security (CENS) of the Nanyang Technological University and the Global Futures Forum (GFF) at Marina Mandarin Hotel, Singapore October 23-25, 2011, <http://declassifiedrommelbanlaoi.blogspot.com/2011/10/bangsamoroism-and-nexus-of-identity.html> (accessed 23 November 2011).

${ }^{102}$ Samuel K. Tan, "Beyond Freedom: The Juma'a Abu Sayyaf (Assessment of Its Origins, Objectives, Ideology and Method of Struggle)", in Internationalization of the Bangsamoro Struggle (Quezon City: University of the Philippines Center for Integrative and Development Studies, 2003), 96.
} 
founded by the Moro volunteers who came to Afghanistan in 1980s to help the mujähideen in fighting the Soviet invasion. It was reported that during his stay in one of the mujāhideen's lair in Pakistan, Janjalani - the leader of the volunteers - came to be acquainted and influenced by Osama bin Laden and Abdur Rasul Sayyaf. The latter was one of the Afghan mujāhideen leaders whose belief in the strict Wahhabi interpretation of Islām found him favourable with many wealthy Saudis, including Osama bin Laden. ${ }^{104}$

Following the Soviet withdrawal from Afghanistan in 1989, Janjalani vowed to bring "jihād qitāl" armed struggle - in the Philippines in order to create a pure Islamic state. His main vision is to return to the fundamentals of Islām by way of strict adherence to its purest form as laid down in the Qur'ān and the Hadith without innovation. He then began traveling around the Muslim World to encourage other MNLF members to help him realize his main objective. In Libya, Janjalani used to tell everyone how Misuari's remote control and dictatorial style of leadership ${ }^{105}$ was damaging the MNLF and losing its people on the ground. Soon, he succeeded in gathering support and organizing a force to push through for an Islamic state.

Janjalani's uncompromising demand is no less than the establishment of an Islamic state in Mindanao. He was in fact quoted as saying that the state he envisions is a state "where Muslims can follow Islam in its purest and strictest form as the only path to Allah." ${ }^{106} \mathrm{He}$ indeed belittled the MNLF for bowing down to the pressure of the OIC members to compromise independence for autonomy. Janjalani made it clear that the only goal of ASG is to rule by the Qur'ān, not autonomy, not the Tripoli Agreement, and not just independence. To make a clear distinction of his ASG from the MNLF, Janjalani distinguished jihād from revolution, in that he was going for the former and Misuari for the latter. For him, the following are the distinctions:

- The first difference is that revolution is not mentioned in the Holy Koran. But jihad is mentioned so many times...

- Second, the command of Allah is to wage jihad, not revolution.

- Third, and as a consequence, if you wage jihad, you must follow the law of Allah. You are not allowed to deviate to the right or the left. If the Koran commands that negotiation is not allowed, there should be no negotiation. In a revolution, you are free to follow the thoughts of Mao Tse-Tung, Lenin, Stalin, Karl Marx, Che Guevara, Ho Chi Minh, Fidel Castro; it's up to you, since you are simply staging a revolution.

- Another difference is, in a revolution, once you win, you are free to select whatever law you want to establish... in jihad, this is not allowed. Upon winning, what you should establish should only be the Koran and the Hadith. These are the only ones to be followed. Nothing else. The objective of jihad is not the implementation of the Tripoli Agreement. It is not the attainment of autonomy. It is not just independence. The objective of jihad is the attainment of independence as a means of establishing the supremacy of the Koran and the Hadith. In jihad, if you win, it should be the laws of the Koran from the beginning, to the middle, to the end... there are no ideas of men to be followed here. ${ }^{107}$

ASG has become known as a radical movement because of its targets of attacks. Since 1991, ASG has been involved in a series of attacks that were mostly directed against Christian churches, missionaries, and nonMuslim civilians. These include the grenade attack in Zamboanga City that killed two American evangelists in 1991; the bombing of the Christian missionary ship, M/V Doulosin Zamboanga, in August 1991; the killing of an Italian priest in Zamboanga on May 20, 1992; the bombing of a building in Zamboanga that killed 2 on August 10, 1992; the kidnapping of two Spanish nuns in Sulu on January 17, 1993; the kidnapping of a Spanish priest on March 18, 1993; the kidnapping of an American missionary in Sulu on November 14, 1993; the bombing of the cathedral in Davao that killed 6 and wounded 132 on December 26, 1993; the series of bombings in Zamboanga that killed over 71 people on June 10, 1994; the attack in Ipil that killed 53 and wounded 48 on April 4, 1995; and the assassination of a Catholic bishop on February 17, $1996 .^{108}$

These attacks have alienated the vast majority of the people and attracted condemnation from the international community. The U.S. Government enlisted ASG as a terrorist group that has link with al Qaeda network. In the Fiscal Years 2002 to 2004, the U.S. Government provided the Philippine military with US\$284.86 million in aid. ${ }^{109}$ In addition to that, some 1,300 U.S. troops, including 160 Special Operations personnel, were brought to the Philippines to engage in a joint training operation with the Philippine Army. ${ }^{110}$

\footnotetext{
${ }^{103}$ Soliman M. Santos, Jr. and Octavio A. Dinampo, 119.

${ }^{104}$ Zachary Abuza, Balik-Terrorism: The Return of the Abu Sayyaf, (Carlisle, Pennsylvania: Strategic Studies Institute, US Army War College, 2005), 2.

${ }^{105}$ Marites D. Vitug \& Glenda M. Gloria, 211.

${ }^{106}$ Marites D. Vitug \& Glenda M. Gloria, 205.

${ }^{107}$ Marites D. Vitug \& Glenda M. Gloria, 212.

${ }_{108}$ Zachary Abuza, 4.

109 Zachary Abuza, 9.

110 Andrew Feickert, U.S. Military Operations in the Global War on Terrorism: Afghanistan, Africa, the Philippines, and Colombia, (Washington, DC: CRS report for Congress, February 2005), 9-12.
} 
On the other hand, the ASG enhanced its cooperation alliances with other movements, most notably the Jamiyah Islamiyah (JI) and the MILF to counterbalance the US-backed Philippine Army. It was reported that ASG and JI were engaged in joint training with emphasis on bomb-making and planning urban bombings. ${ }^{111} \mathrm{By}$ 2005, JI personnel reportedly had trained about 60 ASG Special Forces in bomb assembling and detonations. ${ }^{112}$ Further report revealed that some of the core leaders of ASG were given sanctuary by the MILF leadership. According to the reports, "U.S. signals intercepts have tracked Janjalani from Basilan to Palimbang in Sultan Kudarat, to the Carmen region of North Cotabato, and then to Camp Jabal Quba, a sub-camp of Camp Bushra in Butig, which is the headquarters of the $103^{\text {rd }}$ Base Command." 113 These reports, however, were strongly denied by the MILF, saying that their camps are restricted for their own members and followers.

With the incessant operations by the US-backed Philippine Army, members of the group have decreased from 1000 to 400 . Nevertheless, ASG is still a deadly group that has the capability to carry out sophisticated attacks. Bombs are not the only weapons that they use. The group also organized its urban assassination squad called Fisabilillah, or "The Path of God," in order to have an effective strike in the urban areas. ${ }^{114}$ Indeed, ASG is still a formidable force until today. Rommel Banlaoi, the executive director of the Philippine Institute for Political Violence and Terrorism Research Think-Tank, commented that "they [ASG] have funds to buy bomb ingredients and train potential bombers." 115 The group, therefore, should never be taken for granted. Besides, if people were left no choice, they would fight back no matter how slim the possibility of winning. As Hill boldly commented, "groups like Abu Sayyaf committed regrettable acts of violence, but these actions can hardly be dismissed as 'pointless terrorism', instead, they are the predictable responses of an endangered people." 116

While the Philippine government still enlists the group as a terrorist organization, the members of the group and their supporters firmly believe that they are just a resistance group, committed to defend their own religion and identity. As one of the members suitably comments, ${ }^{117}$ "if the government and the US call us terrorists because we have accidentally killed civilians, then they are more terrorists as there are more blood in their hands. They deliberately killed the Muslim civilians by using their howitzers, areal bombings and drone attacks." Besides, he added, "the main difference of these two killings is, in our case we have to kill for the defence of our religion and our self; but in their case, they kill for the sake of their own personal interests."

\section{Survey And Concluding Remarks}

To sum up, it is important to emphasize that the various liberation movements in Mindanao have the same common goal: that is to free the Bangsamoro people from the yoke of colonialism and to implement Islamic Sharī'ah in the region.

Although some Muslim leaders have cooperated with the government and the MNLF had already signed a final peace agreement, it is also true that many more individuals and organizations have cropped up to continue armed-struggle in order to achieve the ultimate objective: to practice Islam in all aspects of life, including the implementation of Islamic Sharī'ah. For them, provisions in those signed agreements, i.e. Tripoli Agreement and Final Peace Agreement, are insufficient and a subtle way to assimilate the Moros into the Christian cultures and practices. These neophytes want to assert more in order to make Islām as their way of life. To some extent, these neophytes are seen as more aggressive as they continue the armed-struggle and procure more weapons to convey a strong message to the Philippine government that granting complete independence, or at least genuine autonomy, is the only lasting solution to the Mindanao conflict. This demand for making Islam "as a way of life" should not be taken for granted. The more it is overlooked and ignored, the more peace becomes elusive.

The case of the MNLF is a clear example. It was once the strongest and largest organization in Mindanao as it enjoyed the support of the religious group, led by Salamat Hashim. However, its mass support began eroding when Hashim left the organization and founded the MILF. Additionally, ASG also separated from the MNLF with an idea of establishing an Islamic state. The group did not become the largest and strongest organization because of its adherence to more radical strategies and approaches, but its emphasis on Islamic state deserves credit.

\footnotetext{
${ }^{111}$ Terrorism in Southeast Asia, Congressional Research Services, CRS Report for Congress, $2009,17$.

112 Manny Mogato, "Philippine rebels linking up with foreign jihadists, " Reuters News, 21 August $2005,6$.

${ }^{113}$ Zachary Abuza, 17.

${ }^{114}$ Simon Elegant, "The Return of Abu Sayyaf”, <http://www.time.com/time/magazine/article/0,9171,686107,00.html\#ixzz1cQUpnkvS> (accessed 25 December 2011).

115 Agence "Abu Srance-Presse, Sayyaf survives US-backed Philippine crackdown", <http://newsinfo.inquirer.net/breakingnews/nation/view/20091111-235574/Abu-Sayyaf-survives-US-based-Philippine-crackdown> (accessed 25 November 2011).

${ }^{116}$ Fred Hill, "Ethnic cleansing in Mindanao, Philippines" Islamic Horizons, (April, 1996): 1.

${ }^{117}$ The member wants only to be identified as Abu for security reasons.
} 
Currently, the MILF seems to suffer the same internal problem. At least one of the MILF field commanders has publicly expressed his grievances and eventually founded his own armed-fighters, the Bangsamoro Islamic Freedom Fighter (BIFF) ${ }^{118}$ According to $u s t a \bar{z}$ Umbra Kato, the founder of the BIFF, the MILF leadership is now veering away from the Islamic ideology that Hashim had founded. ${ }^{119}$ The present leadership of Al-Haj Murad Ebrahim is not concerned anymore of having an Islamic state. Therefore, it is the duty of the Moros to leave the MILF, and continue fighting for an Islamic state.

The emphasis on the Islamic state must convey a strong message that even the GRP and the MILF signed an agreement, lasting peace could still not be achieved if it does not reflect the real aspiration of the Bangsamoro people. Although BIFF is just a splinter group, it would certainly gain its legitimacy from the people and would become the strongest organization in Mindanao.

This specific proposition is not merely conjectured. It is based on the popular demand of the Moros. Based on the feedback from the questionnaires that the researcher distributed in the areas of Lanao del Sur, Lanao del Norte, Basilan and Maguindanao, it was revealed that almost $100 \%$ of the respondents favour the implementation of Islamic Sharī'ah in Mindanao. Only three out of 400 respondents did not answer in favour of this implementation. Yet, it is interesting to note that even these three respondents also want to have an Islamic Shari' $a h$, but they neither trust the current leadership, nor they believe it is feasible at this time.

Furthermore, the survey ironically shows that some of the respondents who prefer to implement Islamic Shari' $a h$ are not really practicing Muslims. Though most of the respondents adhere to Islamic teachings, at least $37 \%$ of them do not pray five-times a day. That is to say that: out of the 400 respondents, 150 respondents do not completely fulfil the compulsory prayers every day. Other answers of the respondents are summarized in the table below.

Table 1

\begin{tabular}{|c|c|c|c|c|c|c|}
\hline \multicolumn{7}{|c|}{ Number of Respondents from Different Provinces } \\
\hline \multirow{2}{*}{\multicolumn{2}{|c|}{ Questions Asked }} & \multicolumn{5}{|c|}{$\begin{array}{l}\text { Provinces } \\
\end{array}$} \\
\hline & & \multirow{2}{*}{$\begin{array}{l}\text { Lanao del } \\
\text { Sur } \\
97\end{array}$} & \multirow{2}{*}{$\begin{array}{l}\begin{array}{l}\text { Lanao } \\
\text { del Norte }\end{array} \\
30 \\
\end{array}$} & \multirow{2}{*}{$\begin{array}{l}\text { Basilan } \\
47\end{array}$} & \multirow{2}{*}{$\begin{array}{l}\begin{array}{l}\text { Maguin- } \\
\text { danao }\end{array} \\
79\end{array}$} & \multirow{2}{*}{$\begin{array}{l}\text { Total } \\
253\end{array}$} \\
\hline Gender & Male & & & & & \\
\hline & Female & 53 & 20 & 33 & 41 & 147 \\
\hline \multirow[t]{3}{*}{ Age } & Below 21 & 37 & 19 & 24 & 39 & 119 \\
\hline & 21 to 40 & 78 & 23 & 39 & 60 & 200 \\
\hline & 41 and above & 35 & 8 & 17 & 21 & 81 \\
\hline \multirow[t]{3}{*}{ Income } & Below P10,000 & 102 & 30 & 55 & 79 & 266 \\
\hline & $\mathrm{P} 10,000$ to $\mathrm{P} 20,000$ & 35 & 13 & 17 & 30 & 95 \\
\hline & P21,000 and above & 13 & 7 & 8 & 11 & 39 \\
\hline \multirow{5}{*}{$\begin{array}{l}\text { Highest educational } \\
\text { attainment }\end{array}$} & Primary & 0 & 0 & 0 & 0 & $\mathbf{0}$ \\
\hline & Elementary & 5 & 1 & 3 & 3 & 12 \\
\hline & Secondary & 22 & 7 & 10 & 19 & 58 \\
\hline & Tertiary & 116 & 41 & 66 & 94 & 317 \\
\hline & Post-Graduate & 7 & 1 & 1 & 4 & 13 \\
\hline \multirow{2}{*}{$\begin{array}{l}\text { Islamic Education } \\
\text { (Madrasah) }\end{array}$} & Yes & 85 & 17 & 47 & 68 & 217 \\
\hline & No & 65 & 33 & 33 & 52 & 183 \\
\hline \multirow[t]{2}{*}{ Praying 5-times a day } & Yes & 93 & 32 & 48 & 77 & 250 \\
\hline & No & 57 & 18 & 32 & 43 & 150 \\
\hline \multirow[t]{2}{*}{ Giving Zakah } & Yes & 24 & 13 & 12 & 21 & 70 \\
\hline & No & 126 & 37 & 68 & 99 & 330 \\
\hline \multirow{2}{*}{ Fasting during Ramadhan } & Yes & 147 & 49 & 77 & 118 & 391 \\
\hline & No & 3 & 1 & 3 & 2 & 9 \\
\hline \multirow{2}{*}{$\begin{array}{l}\text { Holding government- } \\
\text { related position }\end{array}$} & Yes & 49 & 19 & 23 & 40 & 131 \\
\hline & No & 101 & 31 & 57 & 80 & 269 \\
\hline \multirow{2}{*}{$\begin{array}{l}\text { Moros distinct from } \\
\text { Filipinos }\end{array}$} & Yes & 123 & 41 & 66 & 102 & 332 \\
\hline & No & 27 & 9 & 14 & 18 & 68 \\
\hline \multirow{2}{*}{$\begin{array}{l}\text { Manila-government is a } \\
\text { legacy of Spanish and } \\
\text { American government }\end{array}$} & Yes & 93 & 35 & 58 & 88 & 274 \\
\hline & No & 57 & 15 & 22 & 32 & 126 \\
\hline \multirow{2}{*}{$\begin{array}{l}\text { Government policies are } \\
\text { biased to the Muslims }\end{array}$} & Yes & 101 & 31 & 59 & 85 & 276 \\
\hline & No & 49 & 19 & 21 & 35 & 124 \\
\hline \multirow{2}{*}{$\begin{array}{l}\text { Conflict in Mindanao as a } \\
\text { religious war }\end{array}$} & Yes & 32 & 11 & 28 & 30 & 101 \\
\hline & No & 118 & 39 & 52 & 90 & 299 \\
\hline Islam as a thrusting force & Yes & 132 & 43 & 69 & 107 & 351 \\
\hline
\end{tabular}

${ }^{118}$ Dan G. Cox, "The Bangsamoro Islamic Freedom Fighters and the Future of the Peace Process in the Southern Philippines," Terrorism Monitor, vol.9,

no.34.

<http://www.jamestown.org/programs/gta/single/?tx_ttnews\%5Btt_news\%5D=38380\&cHash=7353290a3c911b33d672ae023b7ce6c4> (accessed 17 February 2012).

${ }_{119}$ Ibid. 
The Liberation Movements In Mindanao: Isläm As A Thrusting Force

\begin{tabular}{|c|c|c|c|c|c|c|}
\hline $\begin{array}{l}\text { for the liberation } \\
\text { movements }\end{array}$ & No & 18 & 7 & 11 & 13 & 49 \\
\hline \multirow{2}{*}{$\begin{array}{l}\text { Islamic Sharia to be } \\
\text { implemented in Mindanao }\end{array}$} & Yes & 150 & 48 & 80 & 119 & 397 \\
\hline & No & 0 & 2 & 0 & 1 & 3 \\
\hline \multirow{2}{*}{$\begin{array}{l}\text { Member of any liberation } \\
\text { movements }\end{array}$} & Yes & 40 & 7 & 11 & 23 & 81 \\
\hline & No & 110 & 43 & 69 & 97 & 319 \\
\hline \multirow{2}{*}{$\begin{array}{l}\text { Member of any other } \\
\text { organization }\end{array}$} & Yes & 122 & 40 & 66 & 100 & 328 \\
\hline & No & 28 & 10 & 14 & 20 & 72 \\
\hline \multirow{2}{*}{$\begin{array}{l}\text { Supporter of the liberation } \\
\text { movements }\end{array}$} & Yes & 149 & 50 & 80 & 120 & 390 \\
\hline & No & 1 & 3 & 1 & 5 & 10 \\
\hline \multirow{3}{*}{$\begin{array}{l}\text { Liberation movements you } \\
\text { prefer }\end{array}$} & MNLF & 29 & 8 & 14 & 9 & 60 \\
\hline & MILF & 105 & 30 & 13 & 103 & 251 \\
\hline & ASG & 16 & 12 & 53 & 8 & 89 \\
\hline \multirow{2}{*}{$\begin{array}{l}\text { Any conflict-related } \\
\text { incident in your place }\end{array}$} & Yes & 33 & 46 & 80 & 109 & 268 \\
\hline & No & 117 & 4 & 0 & 11 & 132 \\
\hline \multirow{2}{*}{$\begin{array}{l}\text { OIC's involvement in } \\
\text { Mindanao is vital }\end{array}$} & Yes & 119 & 41 & 65 & 102 & 327 \\
\hline & No & 31 & 9 & 15 & 18 & 73 \\
\hline
\end{tabular}

Table 1 shows how the four hundred respondents gave various responses to the specific questions. The most significant goal of these questions is to affirm that the Moros, regardless of their personal background, educational attainment, monthly income, and level of piety, have virtually the same desire: to have an Islamic state $^{121}$ in order to implement Islamic Shari' $a h$ in all aspects of life. The respondents, as shown above, do not have to be in a higher level of piety to support the implementation of Shari' $a h$.

The findings also show that: at least 65\% (266) of the respondents have less than P10,000 Pesos a month, 24\% (95) have P10,000 to P20,000 and 10\% (39) have more than P20,000; 3\% (12) have attained elementary-level education, 15\% (58) have attained secondary-level education, 79\% (317) have attained tertiary-level education, and 3\% (13) have post-graduate level of education; 54\% (217) have had an Islamic education and $45 \%$ (183) have not; 35\% (131) reveal that they are government employees, and $65 \%$ are not; $87.5 \%$ (351) consider Islām as a thrusting force for the liberation movement; $97.5 \%$ (390) identify themselves as supporters of the movements, though only $20 \%$ (81) admit to being members of the movements.

Therefore, it is an established fact that majority of the Moros support any liberation movement that champions the realization of an Islamic State and the implementation of Islamic Shari' 'ah. MILF got 62.5\% (251) of the most preferred movements in Mindanao because of its apparent emphasis on Islām.

\footnotetext{
${ }^{120}$ The researcher carried out the survey for 16 days in the provinces of Lanao del Sur, Lanao del Norte, Basilan, and Maguindanao from January 23, 2011 to February 7, 2012. These areas are chosen for being known as the movements' stronghold. The researcher spent five days in Lanao del Sur, three days in Lanao del Norte, three days in Basilan, and four days in Maguindanao. The survey was conducted by distributing questionnaires to the respondents and the researcher allowed them days to answer and return the questionnaires. Furthermore, the respondents come from almost all walks of life. Though university students from various courses and colleges form the majority, there are also respondents who are engineers, economists, accountants, teachers, politicians, businessmen, freelancer, ustaz, and aleems. For those university students, they are from the Mindanao State University in Marawi City, Lanao del Sur, MSU-Iligan Institute of Technology in Iligan City, Lanao del Norte, Notre Deme University in Cotabato City, Maguindanao, and Basilan State College in Isabela City, Basilan. ${ }^{121}$ To make things clear, the researcher has to clarify that neither this whole research, nor this particular survey, is to study in detail the kind of Islamic State and Islamic Sharia the Moros want to implement should they succeed in their struggle. The research and survey are only to establish the fact that the Moros in general have been longing to establish their own Islamic government, in order to guide them in their way of living.
} 